\title{
Overcoming barriers to trust in agricultural biotechnology projects: a case study of Bt cowpea in Nigeria
}

\author{
Obidimma C Ezezika ${ }^{1,2,3^{*}}$, Abdallah S Daar ${ }^{1,4,5}$
}

\begin{abstract}
Background: Nigeria, Africa's most populous country, has been the world's largest cowpea importer since 2004. The country is currently in the early phases of confined field trials for two genetically modified crops: Bacillus thuringiensis (Bt) cowpea and nutritionally enhanced cassava ("BioCassava Plus"). Using the bio-safety guidelines process as a backdrop, we evaluate the role of trust in the operation of the Cowpea Productivity Improvement Project, which is an international agricultural biotechnology public-private partnership (PPP) aimed at providing pest-resistant cowpea varieties to Nigerian farmers.

Methods: We reviewed the published literature and collected data through direct observations and semistructured, face-to-face interviews. Data were analyzed based on emergent themes to create a comprehensive narrative on how trust is understood and built among the partners and with the community.

Results: Our findings highlight the importance of respecting mandates and eliminating conflicts of interest; holding community engagement initiatives early on; having on-going internal discussion and planning; and serving a locally-defined need. These four lessons could prove helpful to other agricultural biotechnology initiatives in which partners may face similar trust-related challenges.

Conclusions: Overcoming challenges to building trust requires concerted effort throughout all stages of project implementation. Currently, plans are being made to backcross the cowpea strain into a local variety in Nigeria. The development and adoption of the Bt cowpea seed hinges on the adoption of a National Biosafety Law in Nigeria. For countries that have decided to adopt biotech crops, the Nigerian cowpea experiment can be used as a model for other West African nations, and is actually applied as such in Ghana and Burkina Faso, interested in developing a Bt cowpea.
\end{abstract}

\section{Background}

\section{Nigeria and the cowpea legume}

Cowpea (known as black-eyed peas in North America) is the most important indigenous African legume because of its ability to grow in drought-prone areas and improve soil fertility. It is the favored crop of small-scale, low-income farmers in Africa [1-3]. It is also a high-protein, low-cost staple food and an important cash crop for farmers [1]. In 2009, the International Institute for Tropical Agriculture (IITA) reported that approximately 7.56 million tonnes of cowpea were produced globally. Nigeria is the largest

\footnotetext{
* Correspondence: obidimma.ezezika@srcglobal.org

'Sandra Rotman Centre, University Health Network and University of

Toronto, Toronto, Ontario, Canada

Full list of author information is available at the end of the article
}

producer and consumer of cowpea in the world, accounting for approximately five million of the 12.76 million total hectares of land devoted to cowpea growth $[4,2,5]$. The enormous demand for cowpeas in Nigeria has made it the world's largest cowpea importer since 2004 [6].

However, cowpea is affected by a number of environmental stressors. The cowpea pod borer (Maruca vitrata) is particularly detrimental. Reports have shown that severe infestations of the Maruca can cause crop yield losses as high as 70-80\% [7]. Insecticides against the Maruca exist but have not been widely adopted by farmers due to prohibitive costs and significant health hazards [7]. Overall, insecticides have proven ineffective in combating the Maruca. 
The purpose of the Cowpea Productivity Improvement Project

The Cowpea Productivity Improvement Project is an agricultural biotechnology (agbiotech) public-private partnership (PPP) that emerged from the recognition of the damage the Maruca pest was doing to cowpea varieties in Africa. This project is the result of a network of individuals and organizations, listed in Table 1, who committed to working together to advance the conventional cowpea seed. This partnership brings together a variety of public, private, research, funding and advocacy organizations (see Additional file 1 for a complete description of these organizations) that fall into three broad categories: project development and technical expertise, funding, and regulatory. These categories denote the primary roles that each group has taken, but are not mutually exclusive.

The Maruca-resistant cowpea was developed by an international agbiotech PPP coordinated by the African
Agricultural Technology Foundation (AATF), a not-forprofit organization that facilitates and promotes PPPs for the benefit of resource-poor smallholder farmers in subSaharan Africa. The Monsanto Company, a multinational agricultural biotechnology company, donated the Bt gene to AATF on a humanitarian basis under a royalty-free license [8]. The Institute for Agricultural Research (IAR) in Zaria, Nigeria was the body responsible for the $c r y 1 A b$ gene introgression into local cowpea varieties. The $c r y 1 A b$ gene is a gene derived from the soil bacterium, Bacillus thuringiensis, which produces specialized proteins to kill specific insects. In this case, the gene is intended to kill the Maruca pod borer [8]. Field testing was then carried out in specific locations in Nigeria.

The main objective of the project is to "enable smallholder farmers in sub-Saharan Africa to have access to farmer-preferred, elite cowpea varieties with resistance to insect pests, especially the pod borer Maruca vitrata" [7].

Table 1 Organizations involved in the Cowpea Productivity Improvement Project

\begin{tabular}{|c|c|c|c|}
\hline Partner & Responsibility & Sector & Contribution \\
\hline $\begin{array}{l}\text { Commonwealth Scientific and Industrial Research } \\
\text { Organisation (CSIRO) }\end{array}$ & Core Partner: Researching transformation methods & Public & $\begin{array}{l}\text { Project } \\
\text { Development } \\
\text { and Technical }\end{array}$ \\
\hline International institute of Tropical Agriculture (IITA) & Core Partner: Working with CSIRO on transformation & Public & $\begin{array}{l}\text { Project } \\
\text { Development } \\
\text { and Technical }\end{array}$ \\
\hline Monsanto Company & Core Partner: Provides insecticide gene, Crylab & Private & $\begin{array}{l}\text { Project } \\
\text { Development } \\
\text { and Technical }\end{array}$ \\
\hline The Kirkhouse Trust & Core Partner: Provides funding for research & Public & Funding \\
\hline $\begin{array}{l}\text { Institute of Agricultural Research (IAR), Zaria, Nigeria } \\
\text { National Agricultural Research Systems in target countries } \\
\text { of West Africa }\end{array}$ & $\begin{array}{l}\text { Core Partner: Institutional biosafety committee; } \\
\text { submitted application for confined field trials (CFT) } \\
\text { Responsible for gene introgression into local cowpea } \\
\text { varieties }\end{array}$ & Public & $\begin{array}{l}\text { Project } \\
\text { Development } \\
\text { and Technical }\end{array}$ \\
\hline $\begin{array}{l}\text { Institut de l'Environnement et Recherches Agricoles } \\
\text { (INERA), Burkina Faso }\end{array}$ & $\begin{array}{l}\text { Core Partner: Helped identify field testing sites, CFT } \\
\text { applications }\end{array}$ & Public & $\begin{array}{l}\text { Project } \\
\text { Development } \\
\text { and Technical }\end{array}$ \\
\hline $\begin{array}{l}\text { National Biotechnology Development Agency (NABDA), } \\
\text { Nigeria }\end{array}$ & $\begin{array}{l}\text { Core Partner: Technical implementation, and regulatory } \\
\text { affairs. }\end{array}$ & Public & $\begin{array}{l}\text { Technology } \\
\text { development }\end{array}$ \\
\hline African Agricultural Technology Foundation (AATF) & Core Partner: Technology acquisition, seed issues & Public & $\begin{array}{l}\text { Project } \\
\text { Development } \\
\text { and Technical }\end{array}$ \\
\hline Program for Biosafety Systems (PBS) & $\begin{array}{l}\text { Regulatory support to NBC/Nigeria and CFT } \\
\text { implementation at IAR. Technical training. }\end{array}$ & Public & $\begin{array}{l}\text { Regulatory } \\
\text { support }\end{array}$ \\
\hline $\begin{array}{l}\text { United States Agency for International Development } \\
\text { (USAID) }\end{array}$ & Funder to CSIRO's efforts, AATF and PBS & Public & Funder \\
\hline Agricultural Research Council of Nigeria (ARCN) & Supervises agricultural research & Public & $\begin{array}{l}\text { Project } \\
\text { Development } \\
\text { and Technical }\end{array}$ \\
\hline $\begin{array}{l}\text { National Agricultural Research Systems (NARS) in target } \\
\text { countries of West Africa }\end{array}$ & Gene introgression into local cowpea varieties & Public & $\begin{array}{l}\text { Project } \\
\text { Development } \\
\text { and Technical }\end{array}$ \\
\hline Rockefeller Foundation & Contributed funds to CSIRO efforts & Public & Funder \\
\hline National Biosafety Committee (NBC) & $\begin{array}{l}\text { Serve as advisory body to the Competent National } \\
\text { Authority for Biosafety in Nigeria (Ministry of } \\
\text { Environment) }\end{array}$ & Public & $\begin{array}{l}\text { Regulatory } \\
\text { authority }\end{array}$ \\
\hline
\end{tabular}


The achievement of this entails three specific objectives: 1) obtain the $c r y 1 A b$ gene from Monsanto, 2) facilitate regulatory compliance for the development of a Marucaresistant cowpea variety, and 3) provide product stewardship for the altered variety [7]. The expected outcomes of the project are increased food production, increased trade between regions in Africa, and elimination of the use of pesticides that are harmful to both humans and the environment [3].

\section{Brief literature review of the history of the Cowpea Productivity Improvement Project}

The Cowpea Productivity Improvement Project is rooted in a longstanding international effort by a group of dedicated scientists to apply the power of research to pressing, humanitarian issues. While the Cowpea Productivity Improvement Project technically began as a project in 2003, its roots reach back to the late 1980s and early 1990s at Purdue University. During this period, scientists from the United States, Italy and Japan, among others, were investigating the potential of genetically modifying the cowpea for specific resistances [9].

In 2001, key international cowpea stakeholders convened for a conference held in Dakar, Senegal and sponsored by a number of institutes including the Food and Agriculture Organization (FAO), IITA, Purdue University and the Rockefeller Foundation. The goal of the meeting was to investigate ways in which the availability of cowpea could be increased [10]. This diverse group of individuals formed the core of the Network for the Genetic Improvement of Cowpea for Africa (NGICA), one of the key partners in the project [10]. In 2002, NGICA convened a workshop in Capri, Italy for those actively engaged in the funded research projects on genetic transformation of cowpea. This workshop sought to encourage discussion between researchers in order to strengthen the NGICA network [11]. Despite NGICA's efforts to encourage scientific research, NGICA remained more of a consortium than a formal organization with an office and staff. Members included researchers from all over Africa as well as the United States and Australia, making the operation of the organization virtual.

NGICA, knowing that a formal organization was necessary to push the project forward, contacted the newly formed AATF as a potential partner. It was believed that AATF had the organizational capacity to coordinate partners and negotiate agreements that NGICA did not have. AATF took on a strong leadership role in the cowpea project and coordinated a second meeting, which was held at their headquarters in Nairobi, Kenya in 2003. The purpose of this meeting was to develop a plan for an AATF/ NGICA cowpea technology transfer project. Five constraint areas were identified and a task force was developed to assess the progress of each sector and develop recommendations for the future. The areas include: seed production and access; field production; storage and utilization; marketing; and intellectual property [12]. The findings that resulted from these task forces determined the agenda for the next planned meeting.

In 2004, a Cowpea Stakeholders Workshop was held to develop a strategic plan for the improvement of cowpea [13]. This workshop integrated knowledge from different stakeholder groups and established technical milestones. Intellectual property rights issues were addressed and a plan to acquire the crylab gene from the Monsanto Company was developed [13,14]. The major outputs of this included the development of a project framework for the Cowpea Productivity Improvement Project including technical plans, a funding breakdown, and a management system structure.

Between 2005 and 2007, countries interested in the Cowpea Productivity Improvement Project went into negotiation to formally define partner roles and develop formal partnership agreements. During the same period, the Commonwealth Scientific and Industrial Research Organisation (CSIRO) in Australia, funded by the Rockefeller Foundation, had begun an experiment to see if genes could be inserted into cowpea varieties. In 2005, CSIRO scientists successfully inserted transgenes into cowpeas that were transmitted to their progeny [15]. In 2007, the AATF had successfully negotiated access to Monsanto's $c r y 1 a b$ gene and the gene had been incorporated into the cowpea at CSIRO in Australia. Testing of this variety against pests had also begun in Australia. The variety was being tested against the Helicoverpa armigera pest, as the Maruca is not present in Australia [16].

In 2007, a meeting was held in Accra, Ghana to develop the application for genetically modified (GM) cowpea confined field trials (CFTs) in Nigeria. By this point, an initial procedure of transforming the Bt gene into a Nigerian wild-type variety had occurred in Australia. However, the challenge of bringing the seed to Nigeria for CFTs remained [16]. Nigeria at this point had ratified the Cartagena Protocol in 2000 and had developed National Biosafety Guidelines through the United Nations Environment Programme-Global Environment Facility (UNEP-GEF) in 2005. These interim guidelines allow for the testing of GM crops for research purposes, but do not allow for commercialization. An application for CFTs was developed after this meeting and submitted to the National Biosafety Committee of Nigeria for review [16].

In 2008, despite the need to evaluate the crops in the field, the hope of experimental trials of Bt cowpea in Nigeria seemed slim. In order to keep the project moving, the partners collectively decided to initiate the first CFTs of the Bt cowpea in August 2008 in Puerto Rico [16]. The trials in Puerto Rico were important to evaluate the efficacy of the Bt events against the pod borer in the field. 


\section{Trust in agbiotech initiatives}

Nigeria is in the midst of developing its regulatory capacity and is in the final stages of passing a formal biosafety law for the safe development and use of GM crops in the country $[17,18]$. Such biosafety capacity provides an important backdrop for the development of biotech development initiatives such as the Cowpea Productivity Improvement Project, which is the focus of this study.

While the goal of the Cowpea Productivity Improvement Project is to provide pest-resistant cowpea varieties to Nigerian farmers, a great obstacle to achieving success with such initiatives is the distrust that may exist among government, regulatory authorities, and the private sector in Nigeria. Trust is important in PPPs, in which groups must collaborate in order to complete complex, longterm tasks [19-21]. In the context of agbiotech projects, these tasks could fall under processes such as product development, regulatory approvals, communication with the public, engagement with farmers, seed multiplication, and breeding, to name a few. Yet, one barrier to establishing trust in past partnerships in Nigeria has been the awareness of corruption at the government level, such as those between civil society organizations and the government [22]. In addition, a history of corruption in Nigerian corporate governance has posed a challenge to attracting foreign investment in the past [23].

Furthermore, establishing and maintaining trust is critical in the agbiotech field as the introduction of transgenic crops can often be contentious and hindered by public distrust $[24,25]$. Particularly, a frequently noted source of distrust in GM crops is a lack of information and awareness across various levels of the public sector. The lack of knowledge about GM crops among both scientists and community members in Nigeria has led to the perception that agricultural biotechnology is risky. Among community members surveyed before participating in informational workshops, the greatest concerns about genetic modification revolved around food safety, ethical issues, and cost [26]. In another survey conducted in southwestern Nigeria, half of the respondents perceived GM crops to be of high risk [27]. For these reasons, the issue of trust in the Bt cowpea project in Nigeria is a critical area worthy of being studied.

This study constitutes one in a series of eight case studies investigating the role of trust in agbiotech PPPs and the adoption of GM crops in sub-Saharan Africa. There are three specific goals of this study: 1) describe effective trust-building practices in agbiotech projects, 2) describe the challenges to trust-building in successful and unsuccessful agbiotech PPPs, and 3) determine what makes these practices effective or ineffective through the identification of barriers to trust and trust-enhancing practices. To our knowledge, it is the first globally-focused case study series of its kind to investigate the role of trust in the successes and failures in PPPs. This study provides insight for potential funders of agbiotech projects as well as for researchers, farmers and others interested in such projects.

\section{Methods}

Data was collected by reviewing academic articles, news articles and publicly available project documents on the cowpea project. We also conducted semi-structured, face-to-face interviews with eleven individuals. These interviewees came from a variety of organizations (listed in Table 1) associated with the project.

Interviewees were identified first by making a list of key individuals associated with the project based on the stakeholders identified within the research protocol. This list was then populated further through snowball sampling by engaging with partners involved in the project and stakeholder informants who were familiar with the Cowpea Productivity Improvement Project through the Sandra Rotman Centre's Social Audit Project [28]. Potential interviewees were sent an invitation, which included an explanation of the case study series, to participate in the interview. Those who consented to participate were informed that the interview would be recorded, transcribed verbatim, and then analyzed. The interviews took place primarily in Nigeria, with some taking place in the United States and one in Tanzania (in accordance to the location in which each stakeholder was based). The interview guide included questions on the interviewees' background, their understanding of the project, and their interpretation of the word trust. The interview explored perceptions of trust within the partnership and the public, apparent challenges to trust, and observed trust-building practices. Interviewees were also asked to provide suggestions on how to improve agbiotech PPPs (see Additional file 2 for sample questions from the interview guide).

The interviews were transcribed and the analysis was performed by reading through the transcripts several times, identifying trends and organizing them into major themes. The results were critically analyzed and compiled to create a comprehensive narrative on how trust is understood and built within the project and between the project and the community that it aims to serve.

We received Research Ethics Board (REB) approval for conducting the case study. Participants provided signed consent to participate in the study and to have the interviews recorded.

\section{Results and discussion}

When developing the interview guide for this study, we did not provide a definition of trust but instead asked the interviewees for their own definition and understanding of trust. While the interviewees linked trust to a number of factors, the strongest link was made to the character of 
the individual or institution. The most frequent descriptions of trust that our interviewees provided were associated with fostering transparency, honesty, accountability, and dependability. However, the diversity of actors involved in the Cowpea Productivity Improvement Project renders trust to exist on different planes, and the level of trust in each of these planes was not identical. For example, we observed a high level of trust among the core partners and a low level of trust between the project partners and the public.

Based on the results of this study, we have derived four key lessons, from which partners in other agbiotech PPPs can learn and use as a guide for building and fostering trust.

\section{Build up, not over: acknowledge existing mandates and institutions}

As the promoter of biotechnology development for Nigeria, it was particularly important for the National Biotechnology Development Agency (NABDA) to recognize each research institution's mandate and existing capabilities when contributing to biotechnology efforts. A government interviewee stated that the government wants to support projects at institutes whose mandates contain no conflicts of interest. This approach not only reduces the redundancies caused by duplication of labor, but also mitigates the potential tensions that could arise among partners.

Some interviewees were concerned that the project might encourage mandate-stealing or result in institutions encroaching on other institutions' area of expertise. At the time of the study, the cowpea project had not encountered any major conflicts in this regard.

Ambiguities in the mandates of partners and organizations involved in the project were, however, a source of distrust in the project. Interviewees stressed that conflicts over ownership and project direction can arise when various stakeholders have diverging understandings about their role in the project. An interviewee cited AATF as an example of an organization that was successful in clarifying its mandate. Their bringing transparency to their plans suggested that both sides of the partnership would be closely involved throughout the entire process.

\section{Educate the public now: information dissemination in the development stages of the project}

Although the commercialization of a Bt cowpea crop is many years away, educating the public was seen as vital to facilitating adoption of the crop, since public trust in biotechnology had already been low. Interviewees mentioned that there were high levels of skepticism within the community due to a lack of familiarity with the genetic transformation process or incorrect knowledge about GM crops. Before introducing a finished GM crop to the
Nigerian market, farmers, journalists, politicians and society at large must first be educated about biotechnology in a language that is understandable. One communications officer noted that people will be more inclined to trust if they understand how a technology was arrived at. To this effect, information-sharing workshops were hosted for farmers, media, and community stakeholders in order to educate the public about the project and GM crops. These efforts were improved by using the appropriate language for different stakeholder groups and making the information as accessible as possible.

\section{Perceptions of GM crops}

A government representative noted that most anti-GM groups counter claims supporting GM without empirical evidence. An interviewee saw some anti-GM groups as purposely wanting to undermine good relations [trust] between project partners and community members. Moreover, communicating accurate information about GM crops to the public was seen as a challenge by some interviewees because of a lack of interest and engagement by scientists and their institutions, as well as the perceived salience of negative gossip among Nigerians regarding GM crops.

\section{Debunking misperceptions}

An interviewee from one of the partner organizations noted that communication with farmers in the beginning will encourage uptake of the product. One approach adopted with regard to this was the organizing of annual visits to the cowpea project lab so farmers and end consumers can see the products being developed. "Farm walks" were also hosted for media representatives and community members to allow them to explore the fields and see the Bt cowpea crops first-hand.

Early information dissemination in the form of flyers, radio broadcasts and educational workshops for community members led to the creation of GM 'ambassadors' community members who understood the benefits of biotechnology and were willing to discuss it informally to others in the community. An interviewee recounted that the Institute for Agricultural Research in Zaria - where the project is being hosted - had many of their students attend this workshop. The students, who did not have much knowledge about biotechnology issues prior to the workshop, became ambassadors that day.

In addition, workshops were held to encourage media, both pro- and anti-GM, to promote accurate information and demystify the concept of GM. A very good example of this as witnessed by one of the authors (OE) was the Open Forum Agricultural Biotechnology (OFAB), which is an organization of public forums on biotechnology that are held on a monthly basis.

Overall, trust between the partners and the community was brought about by engagement and open communication, and reflected in the farmers' and the public's 
receptiveness toward the anticipated product and the increased awareness around agricultural biotechnology.

\section{Team-building as trust-building: establish a core team that works and is results-oriented}

Constructing a core team with defined roles, commitment to the partnership, common goals, and the ability to meet deadlines, manage funds, and communicate effectively is essential to building trust.

\section{Keeping commitments is critical}

Failing to consistently meet deadlines and follow through on commitments was identified as a challenge to building trust within the partnerships. This, according to one government official, was a major challenge to building trust.

A common complaint among interviewees was that some partners were inconsistently meeting deadlines, poorly managing funds, or distracted by other projects. These issues were listed as significant challenges to building trust. Despite these shortcomings, however, one interviewee described the need to keep all partners, particularly public partners, included in order to prevent violating public trust in the project. Effective team-building during the beginning stages of the project is an important practice that can obviate these issues. This would entail establishing and clearly articulating partner roles and the ownership that each partner has over the project when designing the project.

\section{Effective team building}

When team-building is done correctly, the resulting trust among partners can lead to the establishment and continuation of a highly functional partnership [20]. In fact, one of the most prevalent indicators of trust within the relationship was the existence of the partnership itself. An interviewee from the Nigerian government stated that a major indicator of trust is if the partnership is still intact. An officer from the AATF echoed this statement and said that trust helps the project move at the pace expected by partners at any point in time. The trust established by effective team-building can have many positive outcomes, including the pursuit of common goals and open communication among partners [29].

Communication and free expression among partners is also an essential outcome of trust [19]. One researcher stated that communication is absolutely critical for trust building. Another interviewee stated that the ability of partners to express themselves freely - along with any problems or concerns of theirs - is an indication that trust exists in the partnership.

Regular internal communication between partners was also a key driver of project development. Meetings were held monthly and allowed partners to conceptualize project direction, allocate responsibility and establish milestones and objectives. Project partners are also kept updated through the use of bulletins circulated regularly among stakeholders. In addition, high-level expert consultations were held in order to anticipate future challenges. Ongoing daily interactions between partners were also important in ensuring that the team remains intact.

Similarly, critical scientific discussion of the project was a practice that fostered trust within the scientific community. Merits and plans of the cowpea project were debated in a research program review committee, in which the scientists sit together and criticize different projects.

Effective trust-building and team-building enabled two important milestones to be reached: the continuation of funding for the project and the effective delivery of an end product. On the issue of funding and donor support, an interviewee from one of the partner organizations stated that trust motivated the management of his institution to support and continue funding the project. The delivery, eventually, of an end product to the farmers through an efficient and accountable system was viewed as the most obvious result of trust within a partnership. As stated by another interviewee, trust enables a more efficient way of delivering.

\section{Partnering for a purpose: work with local organizations to serve local needs}

The impetus for the cowpea project emerged from a shared recognition of the severity of the pest problem burdening cowpea growers in Nigeria and the inadequacy of regular pest control methods to effectively address it. The need for the project, then, was locally defined by those working with the farmers and addressed by different African agricultural associations. However, the idea that a foreign company is driving the project was deemed a huge challenge that may promote the perception that the private sector has come to exploit poor farmers.

Responding to a locally-defined need was linked to the success and longevity of the project. In addition, one interviewee noted the importance of local capacity-building in research development and infrastructure, which had been integrated into the project. By addressing both the Maruca pest issue and capacity building, the project served two important locally-defined needs.

\section{Negative perceptions of Monsanto and private sector involvement in product development}

Preconceived notions about the private sector varied substantially. Some interviewees saw the Monsanto Company as a positive contributor while others saw it as negative. For example, many interviewees remarked on the minimal role that the private sector had played. An AATF representative stated that, aside from donating the gene, the Monsanto Company does not seem to have anything to do with the actual project. The limited role of Monsanto in the partnership was believed by some to reduce the high level of public suspicion and skepticism of private sector involvement in the project. One interviewee said 
that Monsanto's limited role was important in preventing damage to the trust that had been built within the partnership.

There were still, however, negative perceptions of foreign product development, since the Bt gene was donated by Monsanto and transformation research completed by CSIRO in Australia. An AATF representative stated that he had received negative comments, such as the following: Why are these genes not being used here to develop our own varieties, to have our scientists empowered to use these technologies and to learn. So why is it being developed outside and then we just test and then disseminate... [W] hy not advance our own laboratories? African leadership in the project, such as that of the AATF, was therefore seen as an important factor that built trust between the project and the public.

Despite such perceptions, private sector involvement is regarded by the stakeholders we interviewed as an important component of a PPP's delivery of a successful product. One interviewee, contemplating the nature of the cowpea project as a PPP, expressed concern about the ability of public sector institutions to successfully steward a product such as a GM crop over the longterm and maintain the quality of the seeds and therefore believes that the project must involve more private sector actors.

\section{Conclusions}

As the Cowpea Productivity Improvement Project in Nigeria demonstrates, trust is critical in building successful agbiotech PPPs. Overcoming challenges to trustbuilding requires concerted effort throughout all stages of project implementation. From this case study, four key lessons were drawn on building and maintaining trust among the partners in a project and between the project and the community. First, effective team-building is essential to building trust and ensuring that each partner can and is willing to fulfill their contributions to the project. Second, continuous communication and information sharing among partners and between the partners and the community is an important trust-building practice; this can be accomplished by designing novel and engaging activities that encourage awareness building, such as "farm walks" and the creation of GM 'ambassadors.' Third, building $u p$, not over, existing institutions and mandates serves to encourage trustbuilding by preventing inter-institutional conflicts and mandate-stealing. Fourth, focusing on a locally-defined need and utilizing local organizations through partnership will foster trust and improve project success and longevity. These lessons on trust-building can and should be applied to future projects and agbiotech PPPs. Plans are currently being made to backcross the cowpea strain into a local variety in Nigeria. The further development and adoption of the Bt cowpea seed hinges on, among other things, the adoption of a National Biosafety Law in Nigeria. If the current Biosafety Bill becomes law, some estimates expect that a Bt Marucaresistant cowpea will be available by 2014 for farmers to use [16]. With such a law in place, it is likely that the partners will try to negotiate access to a second gene for the cowpea from Monsanto in order to make the cowpea variety sustainable on the seed market. The Nigerian cowpea experiment can be used as a model for other West African nations, and is actually applied as such in Ghana and Burkina Faso, interested in developing a Bt cowpea.

\section{Additional material}

Additional file 1: Cowpea Productivity Improvement Project core partners.

Additional file 2: Sample questions from the interview guide.

\section{Acknowledgements}

The authors are grateful to each of the participants who contributed substantial time and effort to this study. The authors also thank Kathryn Barber, Jessica Oh, Jocalyn Clark, Hassan Massum, and Jill Murray for comments on earlier drafts of the manuscript. Special thanks to Jill Murray for scheduling the interviews.

This project was funded by the Bill \& Melinda Gates Foundation and supported by the Sandra Rotman Centre, an academic centre at the University Health Network and University of Toronto. The findings and conclusions contained within are those of the authors and do not necessarily reflect official positions or policies of the foundation. This article has been published as part of Agriculture \& Food Security Volume 1 Supplement 1, 2012: Fostering innovation through building trust: lessons from agricultural biotechnology partnerships in Africa. The full contents of the supplement are available online at http://www.agricultureandfoodsecurity.com/ supplements/1/S1. Publication of this supplement was funded by the Sandra Rotman Centre at the University Health Network and the University of Toronto. The supplement was devised by the Sandra Rotman Centre.

\section{Author details}

${ }^{1}$ Sandra Rotman Centre, University Health Network and University of Toronto, Toronto, Ontario, Canada. ${ }^{2}$ African Centre for Innovation and Leadership Development, Federal Capital Territory, Abuja, Nigeria. ${ }^{3}$ Dalla Lana School of Public Health, University of Toronto, Toronto, Canada. ${ }^{4}$ Grand Challenges Canada. ${ }^{5}$ Dalla Lana School of Public Health and Department of Surgery, University of Toronto, Toronto, Canada.

\section{Authors' contributions}

Study conception and design: OCE and ASD. Data collection: OCE. Analysis and interpretation of data: OCE. Draft of the manuscript: OCE and ASD. Critical revision of the manuscript for important intellectual content: OCE and ASD. All authors read and approved the final manuscript.

Competing interests

The authors declare that they have no competing interests.

Published: 1 November 2012

\section{References}

1. Kushwaha S, Musa AS, Lowenberg-DeBoer J, Fulton J: Consumer Acceptance of GMO Cowpeas in sub-Saharan African. Proceedings of the American Agricultural Economics Association Annual Meeting: 3 August 2004: 1-4 August 2004; Denver, CO 2004. 
2. IITA. [http://old.iita.org/cms/details/cowpea_project_details.aspx? zoneid $=63$ \&articleid $=269]$

3. Thomson JA: The role of biotechnology for agricultural sustainability in Africa. Phil Trans R Soc B 2008, 363:905-913.

4. Coulibaly O, Aitchedji C, Gbegbelegbe S, Mignouna H, LowenbergDeBoer J: Baseline Study for Impact Assessment of High Quality Insect Resistant Cowpea in West Africa. African Agricultural Foundation 2008, 1-51.

5. USAID: The Study of the Cowpea Value Chain in Nigeria, from a Pro-Poor and Gender Perspective. 2008, 1-56.

6. David MA: GAIN Report: Nigeria Agricultural Biotechnology Annual Report. United States Department of Agriculture Foreign Agricultural Service; 2009:N19008:1-12

7. African Agricultural Technology Foundation. [http://www.aatf-africa.org/ userfiles/Cowpea-brief.pdf].

8. African Agricultural Technology Foundation: Maruca-Resistant Cowpea: Frequently Asked Questions. [http://www.aatf-africa.org/userfiles/ CowpeaFAQ.pdf].

9. Ferry RL, Singh BB: Cowpea genetics: a review of the recent literature. In Advances in Cowpea Research. Ibadan, Nigeria: ITA:JIRCAS;Singh BB, Mohan Raj DR, Dashiell KE, Jackai LEN 1997:13-29.

10. Murdock LL: Proceedings of the The Dakar Symposium/Workshop on the Genetic Improvement of Cowpea: 8-12 January 2001; Dakar, Senegal. 2001.

11. NGICA: Proceedings of the Workshop on the Genetic Transformation of Cowpea: October 31-November 2 2002; Capri, Italy. 2002.

12. African Agricultural Technology Foundation: Proceedings of the Constraints to Cowpea Production and Utilization in Sub-Saharan African Small Group Meeting: 10-11 July 2003; AATF Headquarters, ILRI, Nairobi, Kenya. 2003.

13. A plan to apply technology in the improvement of cowpea productivity and utilisation for the benefit of farmers and consumers in Africa. In Proceedings of the Small Group Meeting: 10-12 Feb 2004; Accra, Ghana Majiwa P, Odera M, Muchiri N, Omanya G, Werehire P 2004

14. Boadi RY, Bokanga M: The African Agricultural Technology Foundation Approach to IP Management. In Intellectual Property Management in Health and Agricultural Innovation: A Handbook of Best Practices Krattiger A, Mahoney RT, Nelson L 2007, 1765-1774.

15. Popelka JC, Gollasch S, Moore A, Molvig L, Higgins TJV: Genetic transformation of cowpea ( Vigna unguiculata L.) and stable transmission of the transgenes to progeny. Plant Cell Reports 2006, 24(4):304-312.

16. African Agricultural Technology Foundation: Proceedings of the Bt Cowpea Field Trial Planning Meeting Report: 17-18 December 2008; Donald Danforth Plant Science Center, St Louis, Missouri. 2008.

17. Abutu A: Nigeria: Experts Task President Jonathan on Biosafety Bill. All Africa Press; 2012.

18. Okafor J: Nigeria: Biosafety Bill Nears Final 'Push'. All Africa Press; 2011

19. Edelenbos J, Klijn E: Trust in Complex Decision-Making Networks: A theoretical and Empirical Exploration. Administration \& Society 2007, 39(1):25-50.

20. Brewer B, Hayllar MR: Building public trust through public-private partnerships. International Review of Administrative Sciences 2005, 71(3):475-492.

21. White-Cooper S, Dawkins NU, Kamin SL, Anderson LA: Communityinstitutional partnerships: understanding trust among partners. Health Educ Behav 2009, 36(2):334-347.

22. Essia U, Yearoo A: Strengthening civil society organizations/government partnership in Nigeria. International NGO Journal 2009, 4(9):368-374.

23. Okike ENM: Corporate Governance in Nigeria: The Status Quo. Corporate Governance 2007, 15(2):173-193.

24. Friedberg SE, Horowitz L: Converging Networks and Clashing Stories: South Africa's Agricultural Biotechnology Debate. Africa Today 2004, 51(1):3-25.

25. Stone GD: Both Sides Now. Fallacies in the Genetic-Modification Wars, Implications for Developing Countries and Anthropological Perspectives. Current Anthropology 2002, 43(4):611-630.

26. Oladele Ol, Adekoya AE: Improving Technology Perception through Information and Education: A case of Biotechnology in Nigeria. Agriculturae Conspectus Scientificus 2008, 73(4):239-243.
27. Alarima Cl: Knowledge and Perception of Genetically Modified Foods Among Agricultural Scientists in South-West Nigeria. OIDA International Journal of Sustainable Development 2011, 2(6):77-88.

28. Ezezika OC, Thomas F, Lavery JV, Daar AS, Singer PA: A Social Audit Model for Agro-biotechnology Initiatives in Developing Countries: Accounting for Ethical, Social, Cultural and Commercialization Issues. Journal of Technology Management and Innovation 2009, 4(3):24-33.

29. Clark RD: Components of selected public-private partnerships to build new schools in California. University of La Verne; 2002.

doi:10.1186/2048-7010-1-S1-S5

Cite this article as: Ezezika and Daar: Overcoming barriers to trust in agricultural biotechnology projects: a case study of Bt cowpea in Nigeria. Agriculture \& Food Security 2012 1(Suppl 1):S5.

\section{Submit your next manuscript to BioMed Central and take full advantage of:}

- Convenient online submission

- Thorough peer review

- No space constraints or color figure charges

- Immediate publication on acceptance

- Inclusion in PubMed, CAS, Scopus and Google Scholar

- Research which is freely available for redistribution 